\title{
Synthesis of thienyl analogues of PCBM and investigation of morphology of mixtures in P3HT
}

\author{
Fukashi Matsumoto ${ }^{*}$ Kazuyuki Moriwaki, Yuko Takao and Toshinobu Ohno*
}

\section{Full Research Paper}

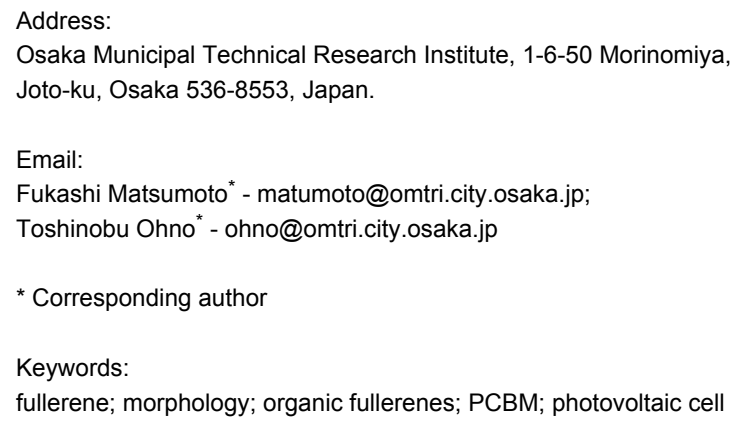

\section{Open Access}

Beilstein Journal of Organic Chemistry 2008, 4, No. 33 doi:10.3762/bjoc. 4.33

Received: 30 July 2008

Accepted: 22 September 2008

Published: 29 September 2008

(C) 2008 Matsumoto et al; licensee Beilstein-Institut. License and terms: see end of document.

\begin{abstract}
Novel [6,6]-phenyl-C61-butyric acid methyl ester (PCBM) analogues containing benzo[b]thiophene (3a, 3b) and thieno[3,2b]thiophene (3c, 3d) were synthesized and characterized. The morphology of the thin films prepared from the mixtures of these methanofullerenes with regioregular poly(3-hexylthiophene) (P3HT) was investigated by AFM measurement and UV-Vis absorption spectroscopy. A solubility test of these methanofullerenes was performed by using dichloromethane as a solvent. es-TThCBM (3d) exhibited 1.4 times greater solubility in dichloromethane than PCBM.
\end{abstract}

\section{Introduction}

The demand for inexpensive, renewable energy sources continues to stimulate new approaches to the production of efficient, low-cost photovoltaic (PV) devices [1-3]. In particular, the use of polymers for the fabrication of solar cells would offer considerable advantages such as the low-cost production of large-area, flexible, and light solar cells [4-7]. Recently, bulk heterojunction solar cells consisting of a conjugated polymer (donor) and fullerene derivatives (acceptors) have inspired much scientific research owing to these reasons $[8,9]$. In this research, it has been demonstrated that the PV cells based on regio-regular poly(3-hexylthiophene) (P3HT, Figure 1) with [6,6]-phenyl-C61-butyric acid methyl ester (PCBM, Figure 1) are highly efficient and promising devices [10]. Many efforts have been devoted to improve device efficiency, for example, changing the solvent for the spin coating of the active layer [11, 12], annealing the device to improve the crystallinity of the polymer $[13,14]$, and controlling the growth rate of the organic film $[15,16]$. These studies reported that the morphology of the active layer is a critical factor that determines the device efficiency.

Investigations have been performed for exploring new donor materials for bulk heterojunction PV devices and the first drastic improvement in device efficiency was achieved by replacing the original donor, poly $\{[2-m e t h o x y-5-(3,7-d i m e t h y l-$ octyloxy)-p-phenylene]vinylene (MDMO-PPV, Figure 1), 


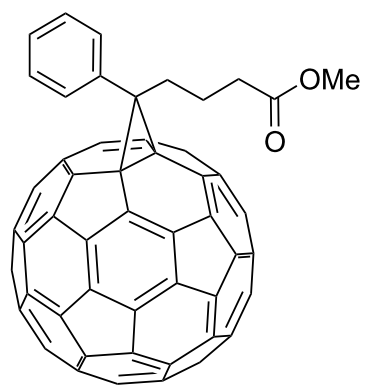

PCBM

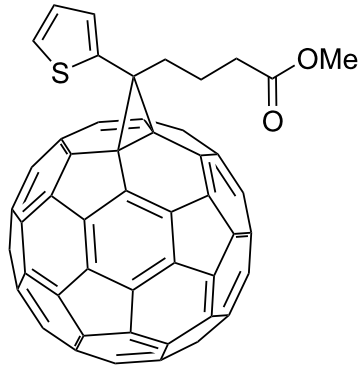

ThCBM

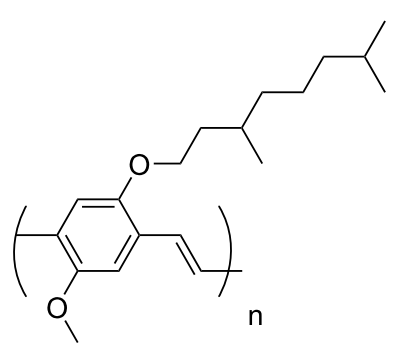

MDMO-PPV

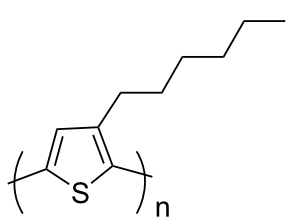

P3HT

Figure 1: Molecular structures of PCBM, ThCBM, MDMO-PPV, and P3HT.

with a high-mobility conjugated polymer, P3HT [17-20]. However, sufficient investigations exploring new acceptor materials have not been performed.

In particular, there is no research focusing on how the structure of fullerene derivatives affects the morphology of the active layer of a PV device. However, it is essential to explore novel fullerene derivatives in order to achieve a significant improvement in the efficiency of PV cells. Recently, Hummelen et al. reported a device fabricated with a thienyl analogue (ThCBM, Figure 1) [21] for the purpose of improving the miscibility with
P3HT. However, there is no obvious explanation related to the advantages of ThCBM over PCBM. In this study, we prepared novel PCBM analogues having various types of thienyl groups and investigated their structural effect on solubility and the morphology of their mixtures with P3HT.

\section{Results and Discussion}

\section{Synthesis of thienyl analogues of PCBM}

Thienyl-substituted methanofullerenes were synthesized by a general procedure [22], as shown in Scheme 1. First, benzo[b]thiophene and thieno[3,2-b]thiophenes were acylated

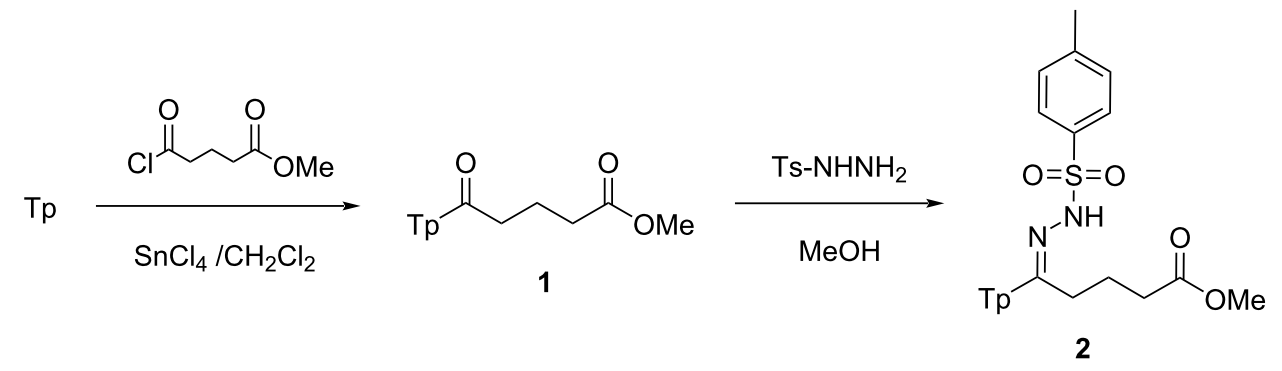

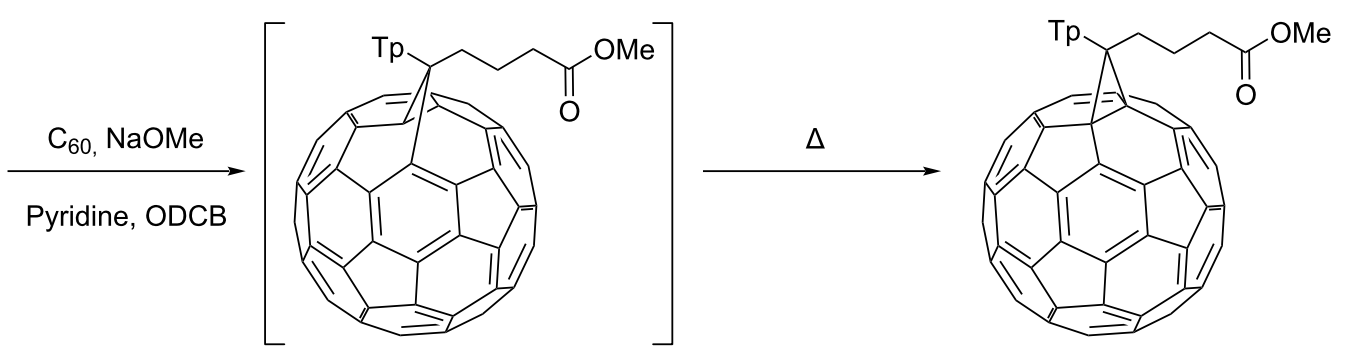

$[5,6]$ Fulleroid
$[6,6]$ Methanofullerene

3<smiles>Cc1cc2ccccc2s1</smiles>

(a)<smiles>Cc1csc2ccccc12</smiles>

(b)<smiles>Cc1cc2sccc2s1</smiles>

(c)<smiles>CCOC(=O)c1cc2sc([13CH3])cc2s1</smiles>

(d) 
by using $\mathrm{SnCl}_{4}$; the acylation was performed at low temperature as a safeguard against the high reactivity of the thienyl groups (yields: 1a; 15\%, 1b; 46\%, 1c; 74\%, 1d; 33\%). Glutaric acid monomethyl ester chloride was used as an acylation reagent in order to form the same structure as that of the butyric acid methyl ester contained in PCBM. The acylation of benzo[b]thiophene yielded 2- and 3-substituted compounds in a 1:3 ratio. These isomers were isolated with a recycling HPLC system using chloroform as an eluent and the compounds 1a and $\mathbf{1 b}$ were easily obtained. Then, the carbonyl group of $\mathbf{1}$ was converted to hydrazone by mixing 1 with $p$-toluenesulfonyl hydrazide. The compounds 2 were obtained as white to pale yellow solids in good yields (2a; 85\%, 2b; 90\%, 2c; 74\%, 2d; $70 \%$ ). The methanofullerenes were prepared from $p$-tosylhydrazones (2) by a one-pot method. A slight excess of $p$-tosylhydrazone (1.2 equiv) was mixed and heated with $\mathrm{C}_{60}$ in the presence of sodium methoxide. The reaction was monitored by TLC and stopped within 3 to $4 \mathrm{~h}$. As expected, the compound 3d exhibited an extremely low $\mathrm{R}_{\mathrm{f}}$ value because of the high polarity of the additional ethyl ester group. During the reaction, mono, di, or highly substituted methanofullerenes were obtained simultaneously; therefore, the monosubstituted methanofullerenes were separated from the mixtures by column chromatography. The products were further purified by reprecipitation from methanol.

In general, the resulting products of the above synthesis process contain the isomers of $[5,6]$ fulleroid (methanoannulene-type bonding) and [6,6]methanofullerene (cyclopropane bonding) [23]. These isomers are clearly distinguishable by the ${ }^{13} \mathrm{C}$ NMR chemical shifts of bridging units. It is well known that $[5,6]$ fulleroid has low solubility and is thermodynamically unstable; hence, it cannot be used in a photovoltaic device. However, except for $\mathbf{2 b}$, the thienyl-substituted hydrazones $\mathbf{2 a}$, 2c, and 2d yielded only [6,6]methanofullerenes. The hydrazone 2b yielded a mixture of $[5,6]$ and $[6,6]$ isomers, probably because of the steric hindrance of benzo[b]thiophen-3-yl or the difference in the electron-donating property between benzo[b]thiophene-3-yl and 2-yl. Therefore, the product $\mathbf{3 b}$ needed heat treatment to convert to $[6,6]$ methanofullerene. In short, thienyl analogues have an advantage over PCBM that they do not need the isomerization step at a temperature as high as $180^{\circ} \mathrm{C}$. The structures of the obtained methanofullerenes (3) were determined by ${ }^{1} \mathrm{H}$ and ${ }^{13} \mathrm{C}$ NMR, IR, and FD-MS spectra. The reaction conditions and product yields are summarized in Table 1.

\begin{tabular}{|lllllll|}
\hline \multicolumn{7}{|l|}{ Table 1: Reaction conditions and yields of methanofullerenes. } \\
\hline Product & $\mathbf{2} / \mathrm{C}_{60}$ & $\begin{array}{l}\text { Temp } \\
\left({ }^{\circ} \mathrm{C}\right)\end{array}$ & $\begin{array}{l}\text { Time } \\
\text { (h) }\end{array}$ & Condition $^{\mathrm{a}}$ & $\begin{array}{l}\text { Yield } \\
(\%)\end{array}$ \\
\hline 2-BThCBM (3a) & 1.2 & 100 & 4 & - & 39 \\
3-BThCBM (3b) & 1.2 & 100 & 4 & $180{ }^{\circ} \mathrm{C}, 12 \mathrm{~h}$ & 32 \\
TThCBM (3c) & 1.2 & 100 & 4 & - & 33 \\
es-TThCBM (3d) & 1.2 & 100 & 3.5 & - & 42 \\
\hline
\end{tabular}

aThermal conversion from $[5,6]$ fulleroid to $[6,6]$ methanofullerene in ODCB.

\section{Solubility of methanofullerenes}

Good solubility of fullerenes is important for fabricating a photovoltaic device with good morphology [24]. In fact, PCBM is one of the most soluble fullerene derivatives and this is the main reason why it is used for the fabrication of PV cells. Chlorobenzene is normally used as a solvent of P3HT and fullerenes to fabricate a bulk hetero layer by spin coating; however, chlorobenzene almost completely dissolves methanofullerenes and hence cannot be used to determine and compare the solubility of different methanofullerenes at a small scale; therefore, in this study, dichloromethane was used as a solvent in the solubility test. As shown in Table 2, the solubilities of the obtained methanofullerenes (3) and ThCBM were significantly different despite little difference in their structures. Surprisingly, es-TThCBM (3d) exhibited the best solubility of 1.4 times that of PCBM; in contrast, TThCBM (3c) exhibited the lowest solubility. This result plainly indicates that an ester group is a key structure to yield a good solubility. It is very interesting that the solubilities of regioisomers of 2-BThCBM (3a) and 3-BThCBM (3b) were extremely different; however, the reasons related to the difference of structures are unknown. ThCBM exhibited a lower solubility than those of PCBM and 2-BThCBM (3a).

It is important that the solubility of es-TThCBM (3d) exceeds that of PCBM, which is promising to obtain better and thick active layers for PV cells.

\begin{tabular}{lllllll}
\hline \multicolumn{2}{l}{$\begin{array}{l}\text { Table 2: Solubility of methanofullerenes } \\
\end{array}$} & & & & & \\
& PCBM & ThCBM & 2-BThCBM (3a) & 3-BThCBM (3b) & TThCBM (3c) & es-TThCBM (3d) \\
\hline $\mathrm{mmol} / \mathrm{L}$ & 17.6 & 10.4 & 13.2 & 3.51 & 3.05 & 23.8 \\
$\mathrm{~g} / \mathrm{L}$ & 16 & 9.56 & 13.1 & 3.49 & 2.96 & 24.9 \\
\hline
\end{tabular}

${ }^{a}$ maximum solubility in dichloromethane. 


\section{Investigation of morphology}

Bulk hetero films of these novel methanofullerenes were spin coated on glass substrates and were characterized by using AFM and UV-Vis absorption spectroscopy in order to study and compare their morphological features. 3-BThCBM (3b) and TThCBM (3c) were excluded because their high-concentration solutions could not be prepared in the solvents used in this study. The bulk hetero films were prepared as follows. Regioregular P3HT and methanofullerene (either 3a or 3d) were dissolved in chlorobenzene at a 1:0.8 wt ratio, followed by filtration. Then, the solution was directly spin coated on a freshly rinsed glass plate and dried for $24 \mathrm{~h}$ at room temperature under vacuum.

Tapping-mode AFM measurements were performed on a film area of $500 \times 500 \mathrm{~nm}$. All films had a very flat surface and almost the same roughness (r.m.s. value of $0.2-0.24 \mathrm{~nm}$ ). However in the phase image (Figure 2), (A) PCBM and (B) ThCBM appear to have coarse features as compared with $(\mathrm{C})$ 2-BThCBM (3a) and (D) es-TThCBM (3d). These chainlike features (bright area) are assigned to the domains of P3HT crystallites. The area between these features consists of either fullerene clusters or a P3HT/fullerene mixture [25]. The domain sizes in the images of PCBM and ThCBM are slightly larger (4-5 nm) than those of 2-BThCBM (3a) and es-TThCBM (3d). The separation distances of these features in PCBM and ThCBM are also longer by 5 to $10 \mathrm{~nm}$ than those in 2-BThCBM (3a) and es-TThCBM (3d). This result indicates that PCBM and ThCBM have large crystallites of P3HT, while 2-BThCBM (3a) and es-TThCBM (3d) mainly consist of amorphous domains of a P3HT/fullerene mixture.

This distinction was also observed in UV-Vis absorption spectra (Figure 3). (A) PCBM and (B) ThCBM exhibited absorption shoulders around 550 and $600 \mathrm{~nm}$, while (C) 2-BThCBM (3a) and (D) es-TThCBM (3d) showed smooth slopes without such shoulders. As is generally known, the peak at $500 \mathrm{~nm}$ is derived from $\mathrm{P} 3 \mathrm{HT}$, almost independent from methanofullerene. Thus, the difference in the shapes of the peaks should be attributed to the variation of the solid state of P3HT [26]. When P3HT is in a crystal state, additional peaks are observed at a higher wavelength because of the $\pi-\pi$ interaction between its polymer chains. Therefore, the P3HT contained in the films of PCBM and ThCBM is in a more crystalline state than that contained in the films of 2-BThCBM (3a) and es-TThCBM (3d), which is almost amorphous.

Assuming that the solubility trend of the methanofullerenes is the same in chlorobenzene and dichloromethane, PCBM and es-TThCBM (3d) seem to disperse very well in the mixture and result in more fine morphology. However, the variation of the film morphology had no correlation with the solubility trend of methanofullerenes and was therefore attributed to the structures of the methanofullerenes: 2-BThCBM (3a) and es-TThCBM (3d) are slightly larger than PCBM and ThCBM. The methanofullerenes (3a, 3d) seem to interfere the aggregation of P3HT, which leads to a more amorphous phase. Comparing PCBM and ThCBM, there is no evident difference in their morphology. The improvement in miscibility between P3HT and PCBM by

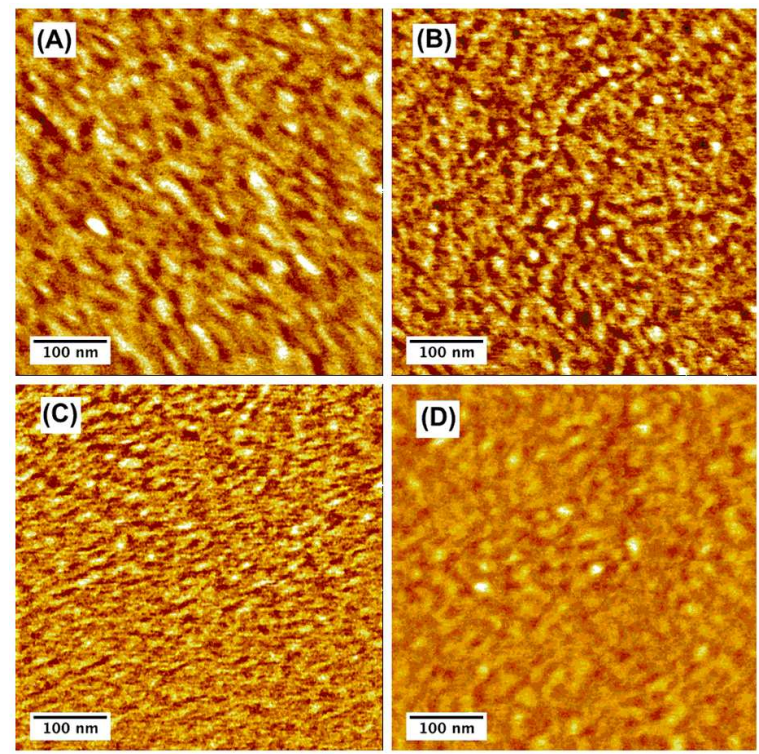

Figure 2: $A F M$ phase images of $\mathrm{P} 3 \mathrm{HT}$ /fullerene blend films containing (A) PCBM, (B) ThCBM, (C) 2-BThCBM (3a), and (D) es-TThCBM (3d) for a $500 \times 500-\mathrm{nm}^{2}$ area.

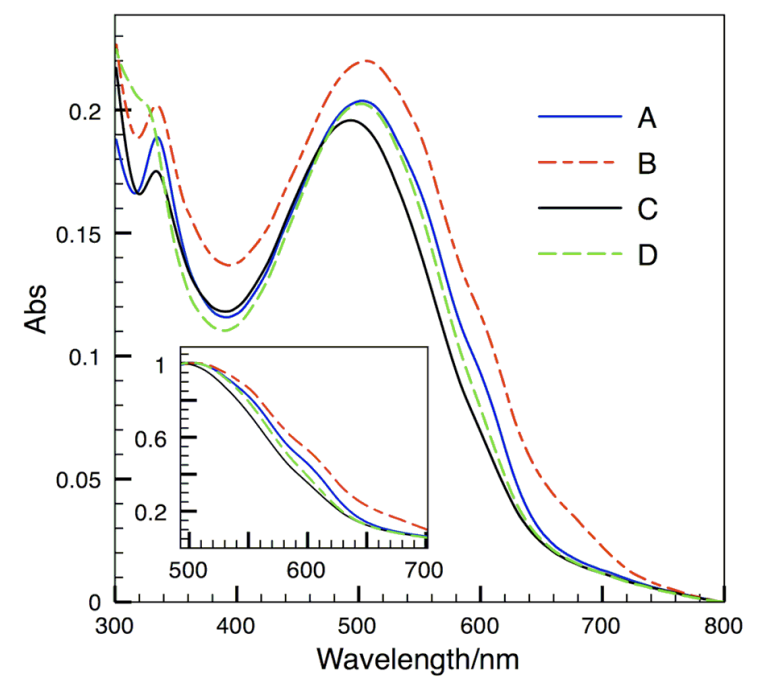

Figure 3: UV-Vis absorption spectra of $\mathrm{P} 3 \mathrm{HT} /$ fullerene blend films for (A) PCBM, (B) ThCBM, (C) 2-BThCBM (3a), and (D) es-TThCBM (3d) Inset: normalized spectra at $500 \mathrm{~nm}$. 
replacing the phenyl group of PCBM by a thienyl group was not clearly confirmed at this stage.

\section{Conclusion}

Novel PCBM analogues containing thienyl groups were synthesized. The morphology of the bulk hetero films of the obtained methanofullerenes was different from that of PCBM. To some extent, the aggregation of $\mathrm{P} 3 \mathrm{HT}$ was restricted by the large volume of 2-BThCBM (3a) and es-TThCBM (3d). Among the obtained methanofullerenes, es-TThCBM (3d) exhibited the best solubility. It is a rare methanofullerene that has greater solubility than PCBM. The improvement in solubility by just adding an ester group is very informative and promising for further development of methanofullerenes. Bulk heterojunction solar cells using newly synthesized methanofullerenes are being fabricated and evaluated.

\section{Supporting Information}

\section{Supporting Information File 1}

Experimental part. Experimental procedures and data for all new compounds

[http://www.beilstein-journals.org/bjoc/content/ supplementary/1860-5397-4-33-S1.doc]

\section{Acknowledgments}

This research work is supported in part by the New Energy and Industrial Technology Development Organization (NEDO) of the Ministry of Economy, Trade and Industry of Japan.

\section{References}

1. Tang, C. W. Appl. Phys. Lett. 1986, 48, 183-185. doi:10.1063/1.96937

2. Brabec, C. J.; Hauch, J. A.; Schilinsky, P.; Waldauf, C. MRS Bull. 2005, $30,50$.

3. Lewis, N. S. Science 2007, 315, 798-801. doi:10.1126/science. 1137014

4. Sariciftci, N. S.; Smilowitz, L.; Heeger, A. J.; Wudl, F. Science 1992, 258, 1474-1476. doi:10.1126/science.258.5087.1474

5. Yu, G.; Gao, J.; Hummelen, J. C.; Wudl, F.; Heeger, A. J. Science 1995, 270, 1789-1791. doi:10.1126/science.270.5243.1789

6. Hoppe, H.; Sariciftci, N. S. J. Mater. Res. 2004, 19, 1924-1945. doi:10.1557/JMR.2004.0252

7. Günes, S.; Neugebauer, H.; Sariciftci, N. S. Chem. Rev. 2007, 107, 1324-1338. doi:10.1021/cr050149z

8. Yu, G.; Heeger, A. J. J. Appl. Phys. 1995, 78, 4510-4515. doi:10.1063/1.359792

9. Kim, Y.; Cook, S.; Choulis, S. A.; Nelson, J.; Durrant, J. R.; Bradley, D. D. C. Chem. Mater. 2004, 16, 4812-4818. doi:10.1021/cm049585c

10. Reyes-Reyes, M.; Kim, K.; Carroll, D. L. Appl. Phys. Lett. 2005, 87, No. 083506. doi:10.1063/1.2006986

11. Yang, X.; Loos, J.; Veenstra, S. C.; Verhees, W. J. H.; Wienk, M. M.; Kroon, J. M.; Michels, M. A. J.; Janssen, R. A. J. Nano Lett. 2005, 5, 579-583. doi:10.1021/nl048120i
12. Al-Ibrahim, M.; Roth, H.-K.; Zhokhavets, U.; Gobsch, G.; Sensfuss, S. Sol. Energy Mater. Sol. Cells 2005, 85, 13-20. doi:10.1016/j.solmat.2004.03.001

13. Chirvase, D.; Parisi, J.; Hummelen, J. C.; Dyakonov, V. Nanotechnology 2004, 15, 1317-1323.

doi:10.1088/0957-4484/15/9/035

14. Camaioni, N.; Ridolfi, G.; Casalbore-Miceli, G.; Possamai, G.; Maggini, M. Adv. Mater. 2002, 14, 1735-1738. doi:10.1002/1521-4095(20021203)14:23<1735::AID-ADMA1735>3.0.C O;2-O

15. Zhang, F.; Svensson, M.; Andersson, M. R.; Maggini, M.; Bucella, S.; Menna, E.; Inganäs, O. Adv. Mater. 2001, 13, 1871-1874. doi:10.1002/1521-4095(200112)13:24<1871::AID-ADMA1871>3.0.CO; 2-3

16. Li, G.; Shrotriya, V.; Huang, J.; Yao, Y.; Moriarty, T.; Emery, K.; Yang, Y. Nat. Mater. 2005, 4, 864-865. doi:10.1038/nmat1500

17. Brabec, C. J.; Cravino, A.; Meissner, D.; Sariciftci, N. S.; Fromherz, T.; Rispens, M. T.; Sanchez, L.; Hummelen, J. C. Adv. Funct. Mater. 2001, 11, 374-380.

doi:10.1002/1616-3028(200110)11:5<374::AID-ADFM374>3.0.CO;2-W

18. Wienk, M. M.; Kroon, J. M.; Verhees, W. J. H.; Knol, J.; Hummelen, J. C.; van Hal, P. A.; Janssen, R. A. J. Angew. Chem., Int. Ed. 2003, 42, 3371-3375. doi:10.1002/anie.200351647

19. Riedel, I.; von Hauff, E.; Parisi, J.; Martín, N.; Giacalone, F.; Dyakonov, V. Adv. Funct. Mater. 2005, 15, 1979-1987. doi:10.1002/adfm.200500097

20. Kim, J. Y.; Lee, K.; Coates, N. E.; Moses, D.; Nguyen, T.-Q.; Dante, M.; Heeger, A. J. Science 2007, 317, 222-225 doi:10.1126/science. 1141711

21. Popescu, L. M.; van't Hof, P.; Sieval, A. B.; Jonkman, H. T.; Hummelen, J. C. Appl. Phys. Lett. 2006, 89, No. 213507. doi:10.1063/1.2397003

22. Hummelen, J. C.; Knight, B. W.; LePeq, F.; Wudl, F.; Yao, J.; Wilkins, C. L. J. Org. Chem. 1995, 60, 532-538. doi:10.1021/jo00108a012

23. Prato, M.; Lucchini, V.; Maggini, M.; Stimpfl, E.; Scorrano, G.; Eiermann, M.; Suzuki, T.; Wudl, F. J. Am. Chem. Soc. 1993, 115, 8479-8480. doi:10.1021/ja00071a080

24. Martens, T.; D'Haen, J.; Munters, T.; Beelen, Z.; Goris, L.; Manca, J.; D'Olieslaeger, M.; Vanderzande, D.; De Schepper, L.; Andriessen, R. Synth. Met. 2003, 138, 243-247. doi:10.1016/S0379-6779(02)01311-5

25. Shrotriya, V.; Yao, Y.; Li, G.; Yang, Y. Appl. Phys. Lett. 2006, 89, No. 063505. doi:10.1063/1.2335377

26. Zhao, Y.; Xie, Z.; Qu, Y.; Geng, Y.; Wang, L. Appl. Phys. Lett. 2007, 90, No. 043504 . doi:10.1063/1.2434173 


\section{License and Terms}

This is an Open Access article under the terms of the Creative Commons Attribution License

(http://creativecommons.org/licenses/by/2.0), which permits unrestricted use, distribution, and reproduction in any medium, provided the original work is properly cited.

The license is subject to the Beilstein Journal of Organic Chemistry terms and conditions:

(http://www.beilstein-journals.org/bjoc)

The definitive version of this article is the electronic one which can be found at:

doi:10.3762/bjoc. 4.33 